\title{
Mixed Cell Adenocarcinoma
}

National Cancer Institute

\section{Source}

National Cancer Institute. Mixed Cell Adenocarcinoma. NCI Thesaurus. Code C4158.

An adenocarcinoma characterized by the presence of a mixed malignant glandular cell population. 